\title{
Completion of the swine genome will simplify the production of swine as a large animal biomedical model
}

\author{
Eric M Walters ${ }^{1 *}$, Eckhard Wolf ${ }^{2}$, Jeffery J Whyte ${ }^{1}$, Jiude Mao ${ }^{1}$, Simone Renner ${ }^{2}$, Hiroshi Nagashima ${ }^{4}$, Eiji Kobayashi ${ }^{3}$, \\ Jianguo Zhao ${ }^{1}$, Kevin D Wells', John K Critser ${ }^{1}$, Lela K Riley ${ }^{1}$ and Randall S Prather ${ }^{1}$
}

\begin{abstract}
Background: Anatomic and physiological similarities to the human make swine an excellent large animal model for human health and disease.

Methods: Cloning from a modified somatic cell, which can be determined in cells prior to making the animal, is the only method available for the production of targeted modifications in swine.

Results: Since some strains of swine are similar in size to humans, technologies that have been developed for swine can be readily adapted to humans and vice versa. Here the importance of swine as a biomedical model, current technologies to produce genetically enhanced swine, current biomedical models, and how the completion of the swine genome will promote swine as a biomedical model are discussed.
\end{abstract}

Conclusions: The completion of the swine genome will enhance the continued use and development of swine as models of human health, syndromes and conditions.

Keywords: Genomic, Pig, Biomedical model, Genetically engineered, Human diseases

\section{Background}

For several decades swine have been a valuable model for human health and disease [1] and cited in [2]. As a general rule, animal models for human disease provide researchers with the knowledge of disease progression, and insights into new therapies. These potential therapies include drug discovery, validation, and toxicology but also can be extended to include gene therapy, surgical interventions and physical therapy. Rodent models, largely the mouse but more recently the rat, have been used widely to study many human health issues [3]. Unfortunately, as in the case of cystic fibrosis, the rodent models do not always fully mimic the relevant human symptoms.

Genetic modification is often required to create, or improve the quality of, a model. Gene transfer into the genome of livestock species was first achieved in 1985 via pronuclear injection [4]. While this was a tremendous

\footnotetext{
* Correspondence: walterse@missouri.edu

${ }^{1}$ National Swine Resource and Research Center, University of Missouri, 920 E. Campus Dr, Columbia, MO 65211 USA

Full list of author information is available at the end of the article
}

advance, transgenesis by pronuclear injection is limited to adding a gene(s) at a random location, and has the potential to cause insertional mutations $[5,6]$ as well as altering the expression of adjacent host DNA sequences. There have been many attempts to overcome this problem by insertion of large DNA fragments (YAC or BACs) [7], and matrix attachment regions or scaffold attachment regions $[8,9]$. With the advent of somatic cell nuclear transfer (SCNT) it became possible to select donor cells with the desired integration prior to creating the animal. While SCNT has been useful for transgenesis, the greater advantage is realized when targeting of a gene via homologous recombination is desired. In mice and recently rats, this is accomplished through the use of embryonic stem cells. However, there has been no verified germ-line competent embryonic stem cell in swine. Despite not having a germline competent ES cell line, investigators have developed induced pig pluripotent cell lines [10-12] which may prove to be useful for the production of genetically modified pigs. Utilizing SCNT seven genes and 1 transgene have been knocked out in swine: alpha 1, 3 galactosyltransferase 
(GGTA1; [13] the cystic fibrosis transmembrane conductance regulator (CFTR; [14,15], Immunoglobulin light chain kappa (IgLK) [16], Immunoglobulin heavy chain (IgH) [17], spinal muscle neuron (SMN; [18]), Green Fluorescent Protein transgene (eGFP; [19]), SIGLEC1 (Whitworth et al. 2011 unpublished data) and peroxisome proliferatoractivated receptor-gamma (PPAR $)$; [20], and there are two knock ins [14]). While the efficiency of cloning still remains low [21] a complete swine genome will enhance the identification and modification of genes that are relevant to human disease. This is especially true for genetic modification of existing genes or inserting a transgene at a given location. Prior to completion of the swine genome the first step in developing a construct was to look comparatively at the sequences of other species. The next step was to search both assembled and raw data for similar sequences. And finally the construct could be built. One of the complications that can arise is the presence or absence of multiple members of a gene family. With the latest draft of the genome completed and the limited annotation associated with it we have some assurance that there is only a single copy a given gene, or multiple family members of the gene. A great example here is $S M N$. In humans there are two spinal muscle neuron genes (SMN1 and SMN2). In pigs there is only a single gene for spinal muscle neuron. In humans mutations in both alleles of SMN1 result in reliance on SMN2 and the development of spinal muscle atrophy (the number one genetic cause of adolescent mortality in North America). Thus to make a model of spinal muscle atrophy one must not only knockout $S M N$, but also a human SMN2 must be added as a transgene [18]. Prior knowledge of the number and location of specific sequences makes these projects move forward much more rapidly.

Completion of the swine genome will be a key informational tool for the understanding of human sequences and their potential role in the development of biomedical models. Using comparative genomics, we can begin to investigate and identify cross-species conserved putative genes and regulatory elements as well as single nucleotide polymorphism of genes specific to human diseases. As an example the completion of the human genome, researchers were able to identify the gene mutation that caused sickle cell anemia [22]. Additionally the completion of the swine genome will be useful in the development of new techniques such as cell-based transgensis. Utilizing cell based transgenesis with site specific modification of the pig genome, one can be begin to modify gene function for the enhanced development of novel disease models in several research areas such as cardiovascular disease, xenotransplantation, and neurodegenerative diseases.

\section{Importance of the pig as a biomedical model}

Although the classical model organisms have provided important information about the basic biology of genes and proteins, these models often have limited usefulness due to their inability to sufficiently represent the human disease. In addition, there has been a dramatic decline in the productivity of new drugs [1] which appears to be associated with the current selection of in vivo models. The current animal models do not reflect the pathophysiology of many human diseases well enough to attain sufficient insight into the efficacy of novel drugs, drug therapy or medical devices; e.g. Cystic Fibrosis [14,15,23], Spinal Muscle Atrophy [18] and Parkinson's Disease [24]. While the pig may not be an obvious choice for a biomedical model, it has been a top choice as a model of human health and disease due to the similarities in anatomy, genetics and pathophysiology.

When compared to other large animal models, swine reach sexual maturity early (6-8 months), have a short gestation length $(\sim 4$ months) and give birth to multiple offspring. Additionally swine are not seasonal breeders and can therefore produce offspring at any time during the year. Due to the economic and agricultural importance of swine, there is a great deal of information, and logistical support on standardized housing, feeding, and reproductive management and healthcare. Swine also provide a variety of genetic backgrounds as there are numerous breeds of both standard and miniature pigs that have been selected to thrive in a variety of environmental conditions. It may be that the different breeds of swine will represent the various ethnic groups from various regions of the world.

Animal models are essential for insight into etiology and pathogenesis of human diseases and the development of new strategies for disease prevention and treatment. With regard to human anatomy, physiology and pathophysiology, the pig is a favorable animal model [25]. Structure and function of the swine gastrointestinal tract as well as the morphology and pharmacokinetics of the pancreas are similar to humans [26]. However one difference between humans and pigs is the lymphatic system as the cortex and medulla of the swine lymph node is reversed compared to the human lymph node [27]. With similarities and differences between pigs and humans we can begin to utilize genomic tools to analyze human diseases and the molecular mechanisms of these diseases in the pig. Previous genetic analysis of the pig has led to identification of a quantitative trait loci for $\mathrm{cu}$ taneous melanoma [28], as well as a novel mutation (Arg to Cys) in the LDL receptor which contributes to spontaneous hypercholesterolemia [29]. Additionally pig models have identified markers for puerperal psychosis [30] and RACK1 as a marker of malignancy for human melanocytic proliferation [31]. As sequences identified in the human are associated with specific disease conditions, an immediate search can be conducted to look for similar genetic variation in the pig. If the variation exists, 
then those animals can be identified and tested; or if the variation does not exist, then a new genetic modification can be contemplated that would recreate the human phenotype. With a sequenced pig genome and the development of new genetic tools such as SNP chips, investigators will continue to perform genetic analysis of pig populations for molecular mechanisms of human diseases.

\section{The pig genome}

The pig genome has been sequenced and is currently being characterized by the Swine Genome Sequencing Consortium (SGSC) using the hybrid approach combining hierarchical shotgun sequencing of BAC clones and whole genome sequencing [32]. By using the $3 x$ coverage of the BACS and the 3x coverage of the whole genome approach, the SGSC will be able to construct a $6 \mathrm{x}$ coverage of the swine genome. Currently the revised assembly (Sscrofa Build 10) has been released and is available for use by the scientific community (ftp://ftp.ncbi.nih. gov/genbank/genomes/Eukaryotes/vertebrates_mammals/ Sus_scrofa/Sscrofa10.2/ or www.ncbi.nlm.nih.gov/genome/ guide/pig/).

The swine genome is comprised of 18 autosomes and 2 sex chromosomes ( $\mathrm{X}$ and $\mathrm{Y}$ chromosomes) and is estimated to be $2.7 \mathrm{~Gb}$. The pig genome is $\sim 7 \%$ smaller than the human, while the mouse and dog genomes are $14 \%$ smaller. In addition to the similarity in size of genome, there is extensive homology of the swine genome to the human. On a nucleotide level swine are $3 \mathrm{x}$ more similar to humans than mice are to humans [34]. On average the synteny blocks of swine-human are farther down the phylogenetic tree than the mouse or dog [34]. Since there are larger syntenic blocks between swine and humans, positional cloning from the pig is generally straightforward and local regulatory interactions between enhancer regions are more likely conserved.

\section{Methods}

\section{Current technologies to produce a TG pig}

While generation of germ-line modified swine via embryonic stem/germ cell technology has not been reported a number of other technologies can be used. These include pronuclear injection [4], oocyte transduction [34,35], embryo transduction [36,37] fibroblast transduction followed by SCNT [35], sperm-mediated gene transfer (SMGT) [38], fibroblast transfection followed by SCNT $[34,35]$, and embryonic germ cell transfection followed by NT [39]. The main advantage of pronuclear injection is that large constructs can be integrated. The main disadvantage of pronuclear injection, oocyte transduction and SMGT is the lack of control over the site of integration. The disadvantage of SCNT is that cloning sometimes results in abnormal animals $[13,40]$ and the efficiencies of producing offspring is low. In addition, porcine fetal fibroblasts used as SCNT donor cells have a finite proliferation capacity and a lower gene targeting frequency as compared to embryonic stem cells available in other species [41]. Despite these challenges, cloning from a modified somatic cell is the only method (Figure 1) available for the production of targeted modifications in swine, and these modifications can be determined in cells prior to making the animal [42].

Potential solutions for improving cloning efficiency have recently focused on the epigenetic regulation of development. Completion of the swine genome will be instrumental in these efforts. Successful cloning by SCNT depends on erasure of somatic cell epigenetic modifications (e.g. histone acetylation and genomic DNA methylation) during pre-zygotic reprogramming, followed by a post-zygotic establishment of embryonic modifications that regulate transcription $[43,44]$. This reprogramming is critical to the normal development of cloned animals. Chemical treatments to alter DNA methylation and histone modifications in SCNT donor cells and embryos are used to shift the genome epigenetic state to more closely resemble that of a normally fertilized zygote. This "assisted remodeling" includes the addition of histone deacetylase inhibitors (HDACi) to donor cell and embryo culture medium. One example, Trichostatin A (TSA), can improve in vitro development of SCNT embryos, but TSA is a known teratogen, and adverse effects on development and survival have been reported in some species [45]. Other HDACi with lower toxicity such as Scriptaid [45,46] and sodium butyrate (NaBu; [47]) can markedly improve pig SCNT embryo development when used to treat donor cells and embryos, respectively. To mimic erasure of DNA methylation in donor cells or reconstructed embryos, 5-aza-20-deoxycytidine (5-aza-dC) treatment has been used on bovine donor cells prior to SCNT [48]. This treatment alters the characteristics of the donor cells but does not enhance development in vitro. In swine, 5-aza-dC applied to IVF-produced pig zygotes reveals that DNA of early pig embryos is not subject to active demethylation at the pronuclear stage or to passive demethylation during the cleavage stages [49], as occurs in the mouse [44]. Such differences in response to chemical treatment among species and stage of development highlight the variable nature of the cloning procedure on epigenetic gene regulation (imprinted or non-imprinted). With the more recent DNA sequencing technologies that produce millions of reads there is increasing need for a scaffold to which these reads can be aligned. If these reads were generated by chromatin immuno-precipitation, e.g. methylated DNA, or histones with specific posttranslational modifications, then their alignment to a scaffold that has predicted CpG islands and/or transcription initiation sites would provide insight to regulation of the development of the cloned (or normal) embryo. It may 


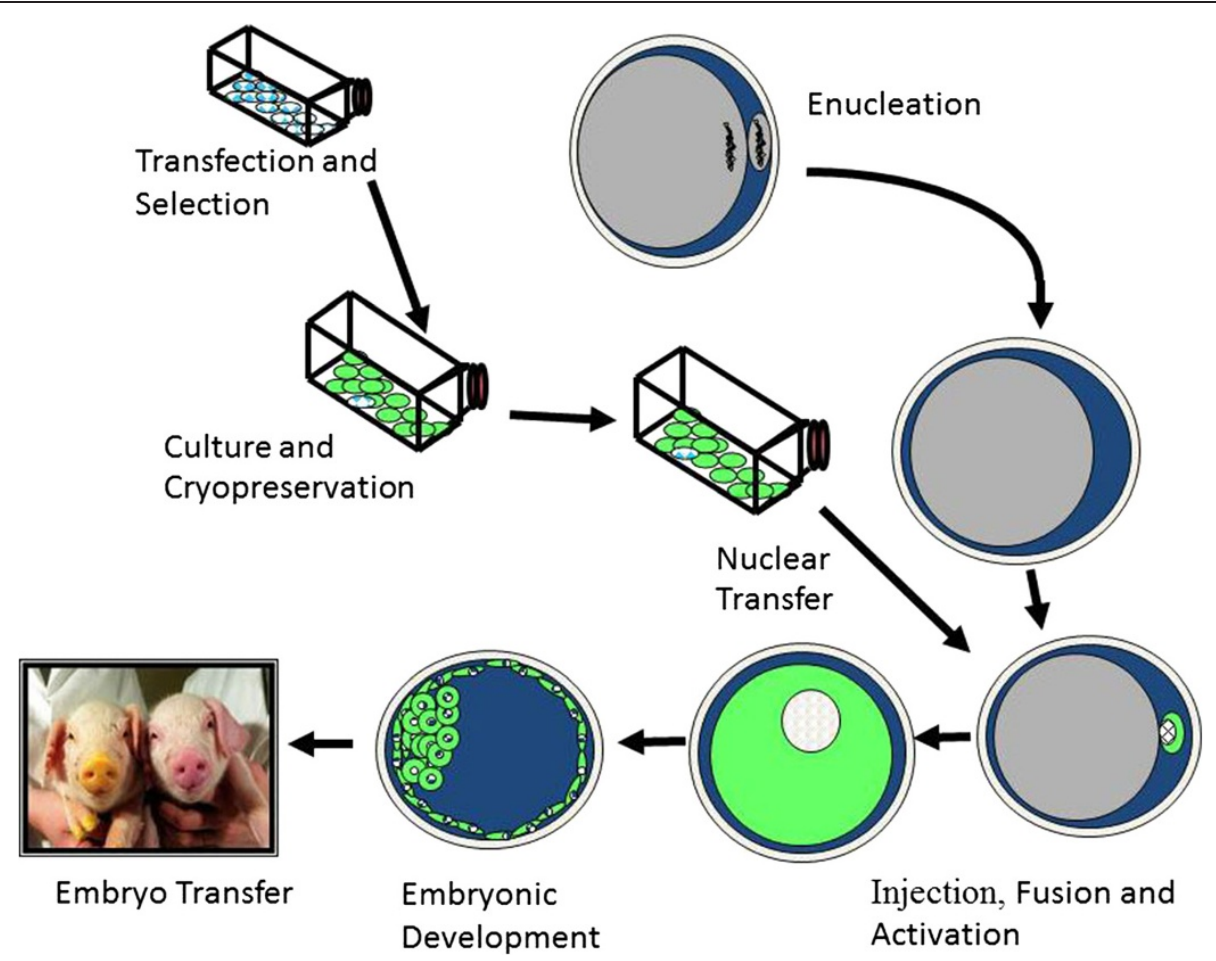

Figure 1 The Somatic Cell Nuclear transfer procedure used to create new genetic modifications [35].

also explain the results from experiments that evaluate the transcriptional profile after, for example, HDACi treatment [50]. Knowledge of the complete pig genome sequence will provide a more detailed understanding of this epigenetic regulation at specific regulatory regions of genes and enable swine-specific refinement of SCNT treatments to improve cloning outcomes [21].

\section{Results}

\section{Genetically engineered biomedical models}

Arguably, the first genetically engineered pigs that modeled a human disorder were produced as an unintended consequence of an attempt to modify growth in production pigs [4]. The growth hormone gene was linked to the methalothionine promoter in the hope of regulating growth by alterations of zinc in the diet. Although the strategy did provide a degree of regulation of the transgene, the basal expression of growth hormone in the uninduced state was sufficiently high to produce an acromegaly phenotype with associated arthritis symptoms. Although some researchers suggested a value of these pigs as a model [51], the transgenic pigs primarily served to help guide future efforts to manipulate growth in agricultural settings.

In 1996, the first intentional transgenic pig model of a human disorder was described for retinitis pigmentosa (RP) [52]. In this genetic disorder, there is a loss of rod cells around puberty that results in loss of sensitive vision ("night blindness"). The loss of rods is followed by the progressive loss of cone cells resulting in loss of peripheral vision that eventually progresses to complete blindness. When transgenic mice were made with the mutant gene, they too developed RP [53]. However, researchers wanted to develop therapeutic interventions with the goal of maintaining the cone cell population after the condition has been diagnosed. The mouse retina, with very few cones, does not provide an adequate model for this phenomenon. However, the pig has a rod to cone ratio almost identical to humans. This model and similar models continues to be used today.

Transgenic pigs will continue to help us to understand the role of genes, advance pharmacological pharming and develop organs for xenotransplantation. In addition, these models will help us to study disease and establish safety and efficacy of new drugs and procedures. Genetic engineering in swine presents the opportunity for targeted genetic manipulations. For an exhaustive list of genetic modifications reported in swine see a review by Whyte and Prather [54]. Below are a few examples of where genetically modified swine have provided insight not otherwise obtainable.

\section{Cystic fibrosis pigs}

In 1938, cystic fibrosis (CF) of the pancreas was first described [55]. Since that time, it has been learned that many other organs are involved (lung, intestine, liver, 
sweat gland, gallbladder and male genital tract) [56]. Cystic Fibrosis is an autosomal recessive disease where approximately 5\% of Caucasians are carriers [57]. Despite identification of the cystic fibrosis transmembrane conductance regulator (CFTR) anion channel as the causative gene for $\mathrm{CF}$ and having a mouse model where CFTR has been disrupted [58], for over 20 years, little advancement has been made in the understanding of CF. Unfortunately, disruption of CFTR in the mouse does not result in a human CF phenotype [59-61]. For those symptoms that are presented in mouse models, such as the intestinal obstruction phenotype that is observed in CFTR-/- mice, the presentation differs from what is observed in humans. In 2008, Rogers et al. reported the development of CFTR-/- and CFTR $\triangle F 508$ swine. Swine were chosen because of their similarity to humans in their anatomy, biochemistry, life span, and genetics [56]. Homologous recombination was used to disrupt CFTR in outbred porcine fibroblast cells. This followed by SCNT and subsequent matings produced homozygous CFTR-/- and CFTR $\triangle F 508 / \triangle F 508$ animals. In approximately $15 \%$ of human CF patients there is an intestinal obstruction observed in the first 48 hours after birth, while in the pig $100 \%$ of the animals are affected $[14,15]$. In addition to the intestinal phenotype these pigs further recapitulate the human phenotype by display of a blocked bile duct, liver lesions, blocked pancreatic duct, and a congealed gallbladder [15,62]. These CF pigs also develop the hallmark phenotype of lung disease [23] and have led to a better understanding of the underlying causes of CF in humans. Unexpectedly, the pig has also led to the identification of low levels of IGF-1 as a possible cause of smaller than average stature among CF patients [63]. The CF pigs will continue to provide the necessary understanding for development of drug therapies or treatment that will aid in prevention of the disease. Prior knowledge from a sequenced genome that there were not multiple gene family members of CFTR would have reduced the risk of the overall project.

\section{Xenotransplantation}

Xenotransplantation is the transplant of cells, tissues or organs from one species to another. The number of people waiting for a suitable organ is over 108,000 (http://www.unos.org/) and there are probably that many people that could benefit from an organ, but are not ill enough to get put on the waiting list. Approximately 10 new patients a day are added to the UNOS waiting list (http://www.unos.org). The number of organ donors for 2009 was only $\sim 14,000$. One way to meet the demand by patients suffering from a wide variety of chronic diseases and end-stage organ failure may be by xenotransplantation. Swine organs may be able to satisfy the unmet and clinical need, but preexisting antibodies that recognize an alpha-1-3-galactosyl ( $\alpha$-gal) epitope result in hyperacute rejection (HAR; [64]). Within minutes swine cells or organs transferred to non-human primates, such as baboons, are destroyed. The $\alpha$-gal residues are synthesized by an enzyme, alpha-1,3-galactosyltransferase, which is encoded by GGTA1. GGTA1 is a pseudogene in humans, apes, and Old World monkeys; however, GGTA1 is functional in most mammals including the pig. In order to utilize swine as a model for xenotransplantation, one of the first obstacles was to remove the $\alpha$-gal epitopes on the swine cells by disruption of GGTA1 [13,65-72]. Other strategies employed to help avoid HAR are the addition of CD55, and/or CD59 on the GGTA1 background, or addition of transgenes encoding enzymes to create carbohydrate structures to cover the gal epitope [73]. In addition to HAR, other genetic modifications have been made to address cell-mediated, acute humoral xenograft, and non-vascular rejections as well as the potential cross species transmission of porcine endogenous retroviruses (PERV; [73]). PERVs are an integral component of the swine genome which are ubiquitously expressed and have has many as 50 proviral loci in the genome depending on the breed of pigs [74]. The majority of the PERVs are defective and are not disease causing in the pigs [75,76]. There are however currently three replication competent subclasses of PERVs (PERV A, B, \& C) that can infect either human (PERV A and C) or pig cells (PERV B) in vitro. With these three subclasses of PERVs that can potentially infect human cells there is a risk of cross species transmission during xenotranplantation. Concerns of PERV infection during xenotransplantation range from acceleration of rejection of the xenograft through a T-cell mediated rejection to providing the necessary sequence to convert an endogenous retrovirus to a replication competent retrovirus [74].

With genetic modifications short term solid organ xenotransplantation from pig to non-human primate has been achieved with 2-6 month survival of heterotropic heart transplants and with life supporting kidney transplant for 3 months [77]. However, lung and liver transplants have not been as successful as the heart and kidney due to thrombotic microangiopathy and coagulation dysfunction. The next big hurdle for xenotransplantation is the acute vascular rejection (AVR) that occurs within hours to days after the transplant. AVR is usually characterized by endothelial activation and cellular damage from thrombotic microangiopathy [78]. However AVR may be overcome by the utilization of genetic engineering. Oropeza et al., [78] reported that the expression of human A20 gene (a TNF-alpha inducible factor) in pigs can provide the protection against apoptotic and inflammatory stimuli. The ability to prolong survival of the pig xenograft appears to be modulated on the ability to produce multi-transgenic pigs 
with sufficient expression levels of all genes involved. The completed genome provides information about the presence and similarity of many of these human genes in the pig. If a given gene product is predicted to be highly homologous to the human protein, then it may not be necessary to add or disrupt that gene for successful xenotransplantation.

\section{Diabetes}

Diabetes mellitus is a group of metabolic disorders characterized by hyperglycemia resulting from impaired insulin secretion or insulin action or a combination of both. In the physiologic state, the two incretin hormones glucose-dependent insulinotropic polypeptide (GIP) and glucagon-like peptide-1 (GLP-1) enhance insulin secretion in a glucose-dependent manner. GIP and GLP-1 are secreted from enteroendocrine cells into the blood in response to nutrients and bind to their specific G-protein coupled receptors, GIPR and GLP-1R respectively, on the pancreatic $\beta$-cells. In type 2 diabetic patients the incretin effect is highly reduced which is mainly related to an impaired insulinotropic action of GIP while the insulinotopic action of GLP-1 is preserved [80]. In order to evaluate the consequences of an impaired GIP action on glucose control and pancreatic islet integrity, transgenic pigs expressing a dominant-negative GIPR (GIPR ${ }^{\mathrm{dn}}$ ) in the pancreatic islets were generated [80] by lentiviral gene transfer [36].

$G I P R^{d n}$ transgenic pigs resemble characteristic features of human type 2 diabetic patients with impaired insulinotropic action of GIP, reduced glucose tolerance and insulin secretion as well as a reduction of $\beta$-cell mass, and are therefore a relevant model for numerous applications in basic as well as in translational research. One area of translational research is the development and preclinical evaluation of incretin-based therapeutics, which is a very active field of clinical research $[81,82]$. These include GLP-1 receptor agonists (GLP-1 analogues and GLP-1 mimetics) as well as inhibitors of the enzyme dipeptidyl peptidase-4 (DPP-4) [83], which rapidly degrade incretin hormones in vivo. Again, a completed genome will provide the number of family members and similarity of the members of the glucose homeostasis regulatory pathway(s). Such knowledge will better direct research to create better models, treatments and therapies for diseases such as diabetes.

\section{Discussion}

\section{Genetic engineering and genetic tools}

Introduction of exogenous DNA into the swine fibroblast prior to SCNT or into the pronucleus or early embryo [84-88] has been performed utilizing several different strategies which have included lipid based delivery $[89,90]$, viral delivery $[13,14,57]$ and electroporation
$[65,70,92]$. Even though these methods can produce genetically modified swine, these methods utilize random integration of the exogenous DNA into the swine genome that occurs utilizing the double strand DNA break repair system. Since DNA integration employs the double stranded DNA break repair system, linearized DNA will integrate $5 \mathrm{x}$ greater than supercoiled DNA [92]. One of the pitfalls of this breakage of plasmid DNA is that cells could potentially be drug-selected positive but not express the transgene. In addition, it is thought that concatamers are more likely to occur with the random integration of plasmid DNA which also can potentially silence the transgene [93,94]. Concatamers are head to tail multicopy gene arrays of the exogenous DNA that can occur before or during integration [92]. Another drawback to random integration of exogenous DNA is potential for insertional mutations of the host genome that may alter the phenotype of the organism $[5,6]$.

Gene targeting is a more precise event than pronuclear injection as it utilizes specific modifications to the genomic sequence. Gene modification or introduction of transgenic constructs into the genome of pig donor cells commonly relies on homologous recombination (HR) as described originally in mouse ES cells [95-97]. These HR events can be used to insert large fragments of DNA; however, to be successful $>3 \mathrm{~kb}$ of homologous DNA needs to be used in the targeting vector. Porcine fibroblasts can be transfected with a targeting vector containing the desired mutation. In a small number of cells the targeting vector pairs with the analogous chromosomal sequence, introducing the mutation to the genome by homologous recombination. Cells, screened and identified as targeted, are then isolated and maintained as a clonal population. Targeting frequency by HR is only one in $10^{5}-10^{6}$ cells, even with tissue culture selection procedures [98].

Gene targeting is a valuable tool for the study of in vivo gene expression however sometimes these targeted events can be embryonic lethal. There are genetic methods to avoid this embryonic lethality but still investigate the gene of interest such as inducible and conditional gene inactivation in a tissue specific and time specific manner. The Cre/loxP recombinase system is the most widely used conditional system [99]. The Cre/lox P system utilizes Cre a $38 \mathrm{kDA}$ recombinase from bacteriophage $\mathrm{P} 1$ and loxP which is a 34 bp consensus sequence. The use of lox $\mathrm{P}$ sites in the same orientation will excise any sequence between them when an active Cre is present [99]. The Cre-lox system allows for time specific expression of your transgene in a tissue specific manner if necessary. The Cre-recombinase system has been confirmed to be functional in swine cells under physiological conditions (Wells, unpublished). 


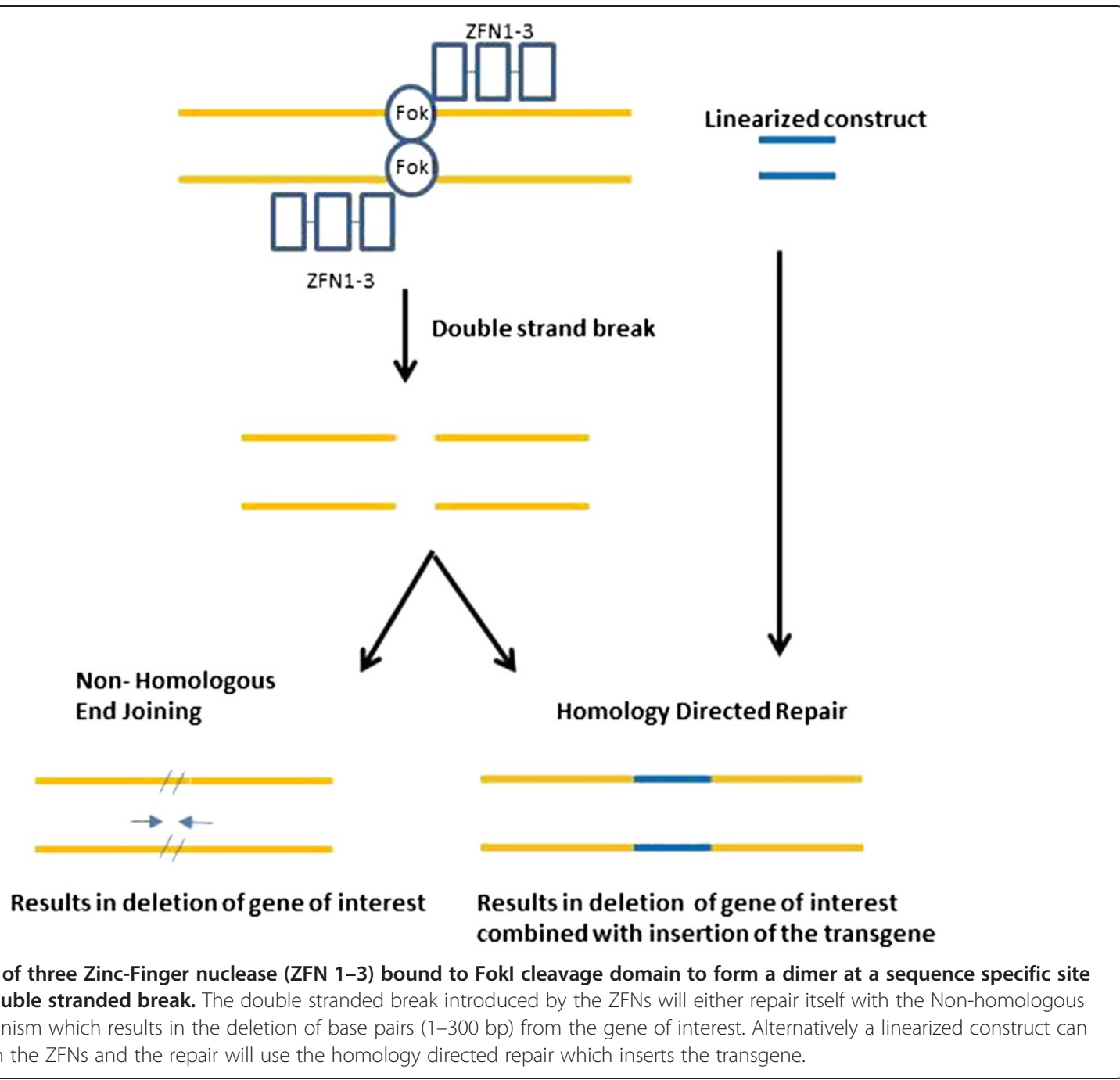

Knowledge of the sequence of the gene of interest, as well as the alternative splice sites, copy number of the number of members of a gene family are very important in developing genetic modifications as described above.

\section{Cell based transgenesis}

With the sequenced pig genome, the use of cell based transgenesis will become a new approach to make genetically modified pigs. Cell based transgenesis allows investigators to make more precise genetic modification by utilizing natural occurring events within the genome such introduction of double stranded DNA breaks at targeted sites.

Zinc fingers nucleases (ZFNs) $[19,100]$ have been used recently to target genetic modifications with a high efficiency. ZFNs have been used in mammalian cells to increase the rate and specificity of gene alteration and transgenesis. ZFNs are synthetic proteins composed of a nonspecific FokI cleavage domain and multiple $\mathrm{Cys}_{2} \mathrm{His}_{2}$ zinc finger DNA-binding domains (Figure 1) [101]. The binding of two ZFN-FokI heterodimers to two target sequences on the coding and non-coding DNA strands with a 6 bp separation allows FokI dimerization and subsequent DNA cleavage. The resulting double strand break can increase the frequency of HR-mediated gene targeting by approximately 1000-fold (reviewed in [102]). Linking zinc fingers in tandem to form modules allows for the design of highly specific DNA recognition sequences [103]. The increase in gene targeting by ZFNs is achieved by the activation of DNA repair mechanisms. If transgene DNA is co-transfected with ZFNs, repair of the double strand breaks by HR can result in transgene insertion in close proximity to the cleavage site as shown in Figure 2 [104]. In the absence of donor DNA, repair of the ZFN cut-site by non-homologous end joining (NHEJ) can inactivate a gene by generating localized insertions or deletions (Figure 2) [105]. Recently, commercially produced ZFNs (Sigma-Aldrich, Inc. St. Louis, MO) were used to disrupt a GFP transgene in a primary culture of porcine fetal fibroblasts [100] which were then used to create live piglets [19]. In addition PPAR $\gamma$ has been 
knocked out by the use of ZFN technology [20]. Insertion of transgenes and/or gene deletions generated by ZFNs in pig fibroblasts could potentially enhance the efficiency of transgenic swine by SCNT. Currently there is a large undertaking of knocking- out 100 genes related to cardiovascular and renal disease in the rat genome using ZFNs or TALENs (Geurts 2011 personal communication).

Recently, there have been several reports of using Transposons for the production of genetically modified organisms such as fish, frogs, mice, rats, and swine [106-112]. Transposons are discrete and mobile sequences in the genome that do not rely on relationships with other sequences. In mammalian transgenesis, two transposons Sleeping Beauty and piggybac have been used for production of genetically modified swine $[106,107,113,114]$. The transposon system works by having the transgene of interest flanked on both sides with specific terminal repeats that will be used as transposase recognition sites. Once in the host cell, transposase will insert the transgene of interest into the host genome. Modifications to this system have been made to increase the efficiency of the transposon system. Artificial methylation of the transposon, and preference for the plasmid to be in the supercoiled conformation results in an increase number of founders that express the transgene and nearly eliminated the insertion of concatemers into the host genome [115].

\section{Conclusions}

The development of genetically engineered pigs for human health and disease is having a significant impact on the scientific community as well as improving the development of treatments and therapies for human diseases. Currently genetically engineered pig models are being used for analysis of gene function in various human diseases, development of new therapeutic strategies as well as production of biopharmaceutical products. For example it is estimated that $60-100$ transgenic pigs could produce enough Factor IX needed for all the hemophilia B patients in the United States (Velander 2011 personal communication). Presently, there are 7 genes and 1 transgene that have been knocked out/in swine and more are being added to this list each year. Genetically engineered swine modified for specific diseases will permit the invasive monitoring of the development of diseases that previously were beyond the grasp of physicians who only saw the disease in humans. The tools are now available to recreate in swine most any genetic disease that occurs in humans. These new swine models can then be used to test interventions pre-clinical and thus reduce any risk for patients. The completion of the swine genome is providing the platform for discovering which genes are responsible for various genetic diseases, as well as the tool for recreating these mutations in swine such as the increased use of cell based transgenesis in a site specific manner.
Competing interests

The authors declare that they have no competing interests.

\section{Authors' contributions}

This review is an International collaboration between the authors promoting the pig as a large animal biomedical model for the scientific community. Many of these experiments were conducted in the various laboratories of the authors. All authors have read and approved the final manuscript.

\section{Author details}

${ }^{1}$ National Swine Resource and Research Center, University of Missouri, 920 E. Campus Dr, Columbia, MO 65211 USA. ${ }^{2}$ Molecular Animal Breeding and Biotechnology, Department of Veterinary Sciences and Laboratory for Functional Genome Analysis, Feoder-Lynen-Strasse 250, Munich 81377 Germany. ${ }^{3}$ Center for Development of Advanced Technology, Jichi Medical University, 3311-1 Yakushiji, Shimotsuke-shi, Tochigi-ken 329-0498 Japan. ${ }^{4}$ Laboratory of Developmental Engineering, Meiji University, 1-1-1 Higashimita, Tama, Kawasaki 214-8571 Japan.

Received: 8 June 2011 Accepted: 28 October 2011

Published: 15 November 2012

\section{References}

1. Aigner B, Renner S, Kessler B, Klymiuk N, Kurome M, Wunsch A, Wolf E: Transgenic pigs as models for translational biomedical research. $J \mathrm{Mol}$ Med 2010, 88:653-664.

2. Lunney JK: Advances in swine biomedical model genomics. Int J Bio/ Sci 2007, 3:179-184

3. Shultz LD, Ishikawa F, Greiner DL: Humanized mice in translational biomedical research. Nat Rev Immunol 2007, 7:118-130.

4. Hammer RE, Pursel VG, Rexroad CE Jr, RJ W, Bolt DJ, Ebert KM, Palmiter RD, Brinster RL: Production of transgenic rabbits, sheep and pigs by microinjection. Nature 1985, 315:680-683.

5. Walters EM, Bauer BA, Franklin CL, Evans TJ, Bryda EC, Riley LK, Critser JK: Mutational insertion of a ROSA26-EGFP transgene leads to defects in spermiogenesis and male infertility in mice. Comp Med 2009, 59:545-552.

6. Rijkers T, Peetz A, Ruther U: Insertional mutagenesis in transgenic mice. Transgenic Res 1994, 3:203-215.

7. Brem G, Besenfelder U, Aigner B, Muller M, Liebl I, Schutz G, Montoliu L: YAC transgenesis in farm animals: Rescue of albinism in rabbits. $\mathrm{Mol}$ Reprod Dev 1996, 44:56-62.

8. McKnight RA, Spencer M, Wall RJ, Hennighausen L: Severe position effects imposed on a $1 \mathrm{~kb}$ mouse whey acidic protein gene promoter are overcome by heterologous matrix attachment regions. Mol Reprod Dev 1996, 44:179-184.

9. Barash I, Ilan N, Kari R, Hurwitz DR, Shani M: Co-integration of betalactoglobulin/human serum albumin hybrid genes with the entire betalactoglobulin gene or the matrix attachment region element: repression of human serum albumin and beta-lactoglobulin expression in the mammary gland and dual regulation of the transgenes. Mol Reprod Dev 1996, 45:421-430.

10. Esteban MA, Xu J, Yang J, Peng M, Qin D, Li W, Jiang Z, Chen J, Deng K, Zhong $M$, et al: Generation of induced pluripotent stem cell lines from Tibetan miniature pig. J Biol Chem 2009, 284:17634-17640.

11. Ezashi T, Telugu BP, Alexenko AP, Sachdev S, Sinha S, Roberts RM: Derivation of induced pluripotent stem cells from pig somatic cells. Proc Natl Acad Sci U S A 2009, 106:10993-10998.

12. Wu Z, Chen J, Ren J, Bao L, Liao J, Cui C, Rao L, Li H, Gu Y, Dai H, et al: Generation of Pig Induced Pluripotent Stem Cells with a Drug-Inducible System. J Mol Cell Biol 2009, 1:46-54.

13. Lai L, Kolber-Simonds D, Park KW, Cheong HT, Greenstein JL, Im GS, Samuel M, Bonk A, Rieke A, Day BN: Production of alpha-1,3-galactosyltransferase knockout pigs by nuclear transfer cloning. Science 2002, 295:1089-1092.

14. Rogers CS, Hao Y, Rokhlina T, Samuel M, Stoltz DA, Li Y, Petroff E, Vermeer DW, Kabel AC, Yan Z, et al: Production of CFTR-null and CFTR-DeltaF508 heterozygous pigs by adeno-associated virus-mediated gene targeting and somatic cell nuclear transfer. J Clin Invest 2008, 118:1571-1577.

15. Rogers CS, Stoltz DA, Meyerholz DK, Ostedgaard LS, Rokhlina T, Taft PJ, Rogan MP, Pezzulo AA, Karp PH, Itani OA, et al: Disruption of the CFTR gene produces a model of cystic fibrosis in newborn pigs. Science 2008, 321:1837-1841. 
16. Ramsoondar J, Mendicino M, Phelps C, Vaught T, Ball S, Monahan J, Chen S, Dandro A, Boone J, Jobst P, et al: Targeted disruption of the porcine immunoglobulin kappa light chain locus. Transgenic Res 2010, 20:643-653.

17. Mendicino M, Ramsoondar J, Phelps C, Vaught T, Ball S, Leroith T, Monahan J, Chen S, Dandro A, Boone J, et al: Generation of antibody- and B cell-deficient pigs by targeted disruption of the J-region gene segment of the heavy chain locus. Transgenic Res 2011, 20:625-641.

18. Lorson M, Spate L, Samuel M, Murphy C, Lorson C, Prather R, Wells K: Disruption of the Survival Motor Neuron gene in pigs using ssDNA. Transgenic Res 2011, 20:1293-1304.

19. Whyte JJ, Zhao J, Wells KD, Samuel MS, Whitworth KM, Walters EM, Laughlin $\mathrm{MH}$, Prather RS: Gene targeting with zinc finger nucleases to produce cloned eGFP knockout pigs. Mol Reprod Dev 2011, 78:2.

20. Yang D, Yang H, Li W, Zhao B, Ouyang Z, Liu Z, Zhao Y, Fan N, Song J, Tian J, et al: Generation of PPAR[gamma] mono-allelic knockout pigs via zinc-finger nucleases and nuclear transfer cloning. Cell Res 2011, 21:979-982.

21. Whitworth KM, Prather RS: Somatic cell nuclear transfer efficiency: how can it be improved through nuclear remodeling and reprogramming? Mol Reprod Dev 2010, 77:1001-1015.

22. Thein SL, Menzel S: Discovering the genetics underlying foetal haemoglobin production in adults. Br J Haematol 2009, 145:455-467.

23. Stoltz DA, Meyerholz DK, Pezzulo AA, Ramachandran S, Rogan MP, Davis GJ, Hanfland RA, Wohlford-Lenane C, Dohrn CL, Bartlett JA, et al: Cystic fibrosis pigs develop lung disease and exhibit defective bacterial eradication at birth. Sci Trans/ Med 2010, 2:29-31.

24. Swanson KS, Mazur MJ, Vashisht K, Rund LA, Beever JE, Counter CM, Schook LB: Genomics and Clinical Medicine: Rationale for Creating and Effectively Evaluating Animal Models. Exp Biol Med 2004, 229:866-875.

25. Douglas WR: Of pigs and men and research: a review of applications and analogies of the pig, sus scrofa, in human medical research. Space Life Sci 1972, 3:226-234

26. Larsen $\mathrm{MO}$, Rolin $\mathrm{B}$ : Use of the Gottingen minipig as a model of diabetes, with special focus on type 1 diabetes research. ILAR J 2004, 45:303-313.

27. Johnson DK, Wisner ER, Griffey SM, Vessey AR, Haley PJ: Inclair miniature swine melanoma as a model for evaluating novel lymphography contrast agents. In Advances in swine in biomedical research. Edited by Tumbleson ME, Schook L. New York City: Plenum Press; 1996:607-612.

28. Du ZQ, Vincent-Naulleau S, Gilbert H, Vignoles F, Crechet F, Shimogiri T, Yasue H, Leplat JJ, Bouet S, Gruand J, et al: Detection of novel quantitative trait loci for cutaneous melanoma by genome-wide scan in the MeLiM swine model. Int J Cancer 2007, 120:303-320.

29. Grunwald KA, Schueler K, Uelmen PJ, Lipton BA, Kaiser M, Buhman K Attie AD: Identification of a novel Arg-> Cys mutation in the LDL receptor that contributes to spontaneous hypercholesterolemia in pigs. J Lipid Res 1999, 40:475-485.

30. Quilter CR, Gilbert CL, Oliver GL, Jafer O, Furlong RA, Blott SC, Wilson AE, Sargent CA, Mileham A, Affara NA: Gene expression profiling in porcine maternal infanticide: a model for puerperal psychosis. Am J Med Genet $B$ Neuropsychiatr Genet 2008, 147B:1126-1137.

31. Egidy G, Jule S, Bosse P, Bernex F, Geffrotin C, Vincent-Naulleau S, Horak V, Sastre-Garau X, Panthier JJ: Transcription analysis in the MeLiM swine model identifies RACK1 as a potential marker of malignancy for human melanocytic proliferation. Mol Cancer 2008, 7:34.

32. Archibald A, Bolund L, Churcher C, Fredholm M, Groenen M, Harlizius B, Lee KT, Milan D, Rogers J, Rothschild M, et al: Pig genome sequence - analysis and publication strategy. BMC Genomics 2010, 11:438.

33. Wernersson R, Schierup MH, Jorgensen FG, Gorodkin J, Panitz F, Staerfeldt $\mathrm{HH}$, Christensen OF, Mailund T, Hornshoj $\mathrm{H}$, Klein A, et al: Pigs in sequence space: a $0.66 \mathrm{X}$ coverage pig genome survey based on shotgun sequencing. BMC Genomics 2005, :6-70.

34. Cabot RA, Kuhholzer B, Chan AW, Lai L, Park KW, Chong KY, Schatten G, Murphy CN, Abeydeera LR, Day BN, et al: Transgenic pigs produced using in vitro matured oocytes infected with a retroviral vector. Anim Biotechnol 2001, 12:205-214.

35. Park KW, Cheong HT, Lai L, Im GS, Kuhholzer B, Bonk A, Samuel M, Rieke A, Day BN, Murphy CN, et al: Production of nuclear transfer-derived swine that express the enhanced green fluorescent protein. Anim Biotechnol 2001, 12:173-181.

36. Hofmann A, Kessler B, Ewerling S, Weppert M, Vogg B, Ludwig H, Stojkovic M, Boelhauve $M$, Brem $G$, Wolf $E$, et al: Efficient transgenesis in farm animals by lentiviral vectors. EMBO Rep 2003, 4:1054-1060.
37. Whitelaw CB, Radcliffe PA, Ritchie WA, Carlisle A, Ellard FM, Pena RN, Rowe J, Clark AJ, King TJ, Mitrophanous KA: Efficient generation of transgenic pigs using equine infectious anaemia virus (EIAV) derived vector. FEBS Lett 2004, 571:233-236.

38. Lavitrano M, Busnelli M, Cerrito MG, Giovannoni R, Manzini S, Vargiolu A: Sperm-mediated gene transfer. Reprod Fertil Dev 2006, 18:19-23.

39. Ahn KS, Won JY, Park JK, Sorrell AM, Heo SY, Kang JH, Woo JS, Choi BH, Chang WK, Shim H: Production of human CD59-transgenic pigs by embryonic germ cell nuclear transfer. Biochem Biophys Res Commun 2010, 400:667-672.

40. Carter DB, Lai L, Park KW, Samuel M, Lattimer JC, Jordan KR, Estes DM, Besch-Williford C, Prather RS: Phenotyping of transgenic cloned piglets. Cloning Stem Cells 2002, 4:131-145.

41. Zhu H, Tamot B, Quinton M, Walton J, Hacker RR, Li J: Influence of tissue origins and external microenvironment on porcine foetal fibroblast growth, proliferative life span and genome stability. Cell Prolif 2004, 37:255-266.

42. Prather RS, Shen M, Dai Y: Genetically modified pigs for medicine and agriculture. Biotechnol Genet Eng Rev 2008, 25:245-265.

43. Niemann H, Tian XC, King WA, Lee RS: Epigenetic reprogramming in embryonic and foetal development upon somatic cell nuclear transfer cloning. Reproduction 2008, 135:151-163.

44. Zhao J, Whyte J, Prather RS: Effect of epigenetic regulation during swine embryogenesis and on cloning by nuclear transfer. Cell Tissue Res 2010, 341:13-21.

45. Zhao J, Hao Y, Ross JW, Spate LD, Walters EM, Samuel MS, Rieke A, Murphy CN, Prather RS: Histone deacetylase inhibitors improve in vitro and in vivo developmental competence of somatic cell nuclear transfer porcine embryos. Cell Reprogram 2010, 12:75-83.

46. Zhao J, Ross JW, Hao Y, Spate LD, Walters EM, Samuel MS, Rieke A, Murphy CN, Prather RS: Significant improvement in cloning efficiency of an inbred miniature pig by histone deacetylase inhibitor treatment after somatic cell nuclear transfer. Biol Reprod 2009, 81:525-530.

47. Das ZC, Gupta MK, Uhm SJ, Lee HT: Increasing Histone Acetylation of Cloned Embryos, But Not Donor Cells, by Sodium Butyrate Improves Their In Vitro Development in Pigs. Cellular Reprogramming (Formerly "Cloning and Stem Cells") 2010, 12:95-104.

48. Enright BP, Sung LY, Chang CC, Yang X, Tian XC: Methylation and acetylation characteristics of cloned bovine embryos from donor cells treated with 5-aza-2'-deoxycytidine. Biol Reprod 2005, 72:944-948.

49. Jeong YS, Yeo S, Park JS, Koo DB, Chang WK, Lee KK, Kang YK: DNA methylation state is preserved in the sperm-derived pronucleus of the pig zygote. Int J Dev Biol 2007, 51:707-714.

50. Whitworth KM, Zhao J, Spate LD, Li R, Prather RS: Scriptaid corrects gene expression of a few aberrantly reprogrammed transcripts in nuclear transfer pig blastocyst stage embryos. Cell Reprogram 2011, 13:191-204.

51. Fischer KM: Transgenic domestic animals provide an animal model for rheumatoid arthritis. Med Hypotheses 1992, 38:240-243.

52. Petters RM, Alexander CA, Wells KD, Collins EB, Sommer JR, Blanton MR, Rojas G, Hao Y, Flowers WL, Banin E: Genetically engineered large animal model for studying cone photoreceptor survival and degeneration in retinitis pigmentosa. Nat Biotechnol 1997, 15:965-970.

53. Olsson JE, Gordon JW, Pawlyk BS, Roof D, Hayes A, Molday RS, Mukai S, Cowley GS, Berson EL, Dryja TP: Transgenic mice with a rhodopsin mutation (Pro23His): a mouse model of autosomal dominant retinitis pigmentosa. Neuron 1992, 9:815-830.

54. Whyte JJ, Prather RS: Genetic modifications of pigs for medicine and agriculture. Mol Reprod Dev, in press.

55. Andersen $\mathrm{DH}$ : Cystic fibrosis of the pancreas and its relationship to celiac disease; a clinical and pathological study. Am J Dis Child 2011, 56:344.

56. Rogers CS, Abraham WM, Brogden KA, Engelhardt JF, Fisher JT, McCray PB Jr, McLennan G, Meyerholz DK, Namati E, Ostedgaard LS, et al: The porcine lung as a potential model for cystic fibrosis. Am J Physiol Lung Cell Mol Physiol 2008, 295:L240-L263.

57. Rogers CS, Stoltz DA, Meyerholz DK, Ostedgaard LS, Rokhlina T, Taft PJ, Rogan MP, Pezzulo AA, Karp PH, Itani OA, et al: Disruption of the CFTR gene produces a model of cystic fibrosis in newborn pigs. Science 2008, 321:1837-1841.

58. Riordan JR, Rommens JM, Kerem B, Alon N, Rozmahel R, Grzelczak Z, Zielenski J, Lok S, Plavsic N, Chou JL, et al: Identification of the cystic fibrosis gene: cloning and characterization of complementary DNA. Science 1989, 245:1066-1073. 
59. Grubb BR, Boucher RC: Pathophysiology of Gene-Targeted Mouse Models for Cystic Fibrosis. Physiol Rev 1999, 79:S193-S214.

60. Guilbault C, Saeed Z, Downey GP, Radzioch D: Cystic Fibrosis Mouse Models. Am J Respir Cell Mol Biol 2007, 36:1-7.

61. Welsh MJ, Rogers CS, Stoltz DA, Meyerholz DK, Prather RS: Development of a porcine model of cystic fibrosis. Trans Am Clin Climatol Assoc 2009, 120:149-162.

62. Ostedgaard LS, Meyerholz DK, Chen JH, Pezzulo AA, Karp PH, Rokhlina T, Ernst SE, Hanfland RA, Reznikov LR, Ludwig PS, et al: The \{Delta\}F508 Mutation Causes CFTR Misprocessing and Cystic Fibrosis-Like Disease in Pigs. Sci Trans/ Med 2011, 3:74. ra24.

63. Rogan MP, Reznikov LR, Pezzulo AA, Gansemer ND, Samuel M, Prather RS, Zabner J, Fredericks DC, McCray PB Jr, Welsh MJ, et al: Pigs and humans with cystic fibrosis have reduced insulin-like growth factor 1 (IGF1) levels at birth. Proc Natl Acad Sci U S A 2010, 107:20571-20575.

64. Yang $Y$ G, Sykes M: Xenotransplantation: current status and a perspective on the future. Nat Rev Immunol 2007, 07:519-531.

65. Dai Y, Vaught TD, Boone J, Chen SH, Phelps CJ, Ball S, Monahan JA, Jobst PM, McCreath KJ, Lamborn AE, et al: Targeted disruption of the [alpha]1,3-galactosyltransferase gene in cloned pigs. Nat Biotech 2002, 20:251-255.

66. Harrison SJ, Guidolin A, Faast R, Crocker LA, Giannakis C, d'Apice AJ, Nottle $M B$, Lyons I: Efficient generation of alpha(1,3) galactosyltransferase knockout porcine fetal fibroblasts for nuclear transfer. Transgenic Res 2002, 11:143-150.

67. Kolber-Simonds D, Lai L, Watt SR, Denaro M, Arn S, Augenstein ML, Betthauser J, Carter DB, Greenstein JL, Hao Y, et al: Production of alpha-1,3-galactosyltransferase null pigs by means of nuclear transfer with fibroblasts bearing loss of heterozygosity mutations. Proc Natl Acad Sci U S A 2004, 101:7335-7340.

68. Phelps CJ, Koike C, Vaught TD, Boone J, Wells KD, Chen SH, Ball S, Specht SM, Polejaeva IA, Monahan JA: Production of alpha 1,3-galactosyltransferase-deficient pigs. Science 2003, 299:411-414.

69. Ramsoondar JJ, Machaty Z, Costa C, Williams BL, Fodor WL, Bondioli KR: Production of alpha 1,3-galactosyltransferase-knockout cloned pigs expressing human alpha 1,2-fucosylosyltransferase. Biol Reprod 2003, 69:437-445

70. Sharma A, Naziruddin B, Cui C, Martin MJ, Xu H, Wan H, Lei Y, Harrison C, Yin J, Okabe J, et al: Pig cells that lack the gene for alpha1-3 galactosyltransferase express low levels of the gal antigen. Transplantation 2003, 75:430-436

71. Takahagi Y, Fujimura T, Miyagawa S, Nagashima H, Shigehisa T, Shirakura R, Murakami H: Production of alpha 1,3-galactosyltransferase gene knockout pigs expressing both human decay-accelerating factor and $\mathrm{N}$ acetylglucosaminyltransferase III. Mol Reprod Dev 2005, 71:331-338.

72. Watt SR, Betthauser JM, Augenstein ML, Childs LA, Mell GD, Forsberg EJ, Eisen A: Direct and rapid modification of a porcine xenoantigen gene (GGTA1). Transplantation 2006, 82:975-978.

73. Klymiuk N, Aigner B, Brem G, Wolf E: Genetic modification of pigs as organ donors for xenotransplantation. Mol Reprod Dev 2010, 77:209-221.

74. Ramsoondar J, Vaught T, Ball S, Mendicino M, Monahan J, Jobst P, Vance A, Duncan J, Wells K, Ayares D: Production of transgenic pigs that express porcine endogenous retrovirus small interfering RNAs. Xenotransplantation 2009, 16:164-180.

75. Herring C, Quinn G, Bower R, Parsons N, Logan NA, Brawley A, Elsome K, Whittam A, Fernandez-Suarez XM, Cunningham D, et al: Mapping full-length porcine endogenous retroviruses in a large white pig. $J$ Virol 2001, 75:12252-12265.

76. Patience $C$, Takeuchi Y, Weiss RA: Infection of human cells by an endogenous retrovirus of pigs. Nat Med 1997, 3:282-286.

77. Ekser B, Gridelli B, Tector AJ, Cooper DK: Pig liver xenotransplantation as a bridge to allotransplantation: which patients might benefit? Transplantation 2009, 88:1041-1049.

78. Oropeza M, Petersen B, Carnwath JW, Lucas-Hahn A, Lemme E, Hassel P, Herrmann D, Barg-Kues B, Holler S, Queisser AL, et al: Transgenic expression of the human $A 20$ gene in cloned pigs provides protection against apoptotic and inflammatory stimuli. Xenotransplantation 2009, 16:522-534.

79. Nauck MA, Heimesaat MM, Orskov C, Holst JJ, Ebert R, Creutzfeldt W: Preserved incretin activity of glucagon-like peptide 1 [7-36 amide] but not of synthetic human gastric inhibitory polypeptide in patients with type-2 diabetes mellitus. J Clin Invest 1993, 91:301-307.
80. Renner S, Fehlings C, Herbach N, Hofmann A, von Waldthausen DC, Kessler B, Ulrichs K, Chodnevskaja I, Moskalenko V, Amselgruber W, et al: Glucose intolerance and reduced proliferation of pancreatic beta-cells in transgenic pigs with impaired glucose-dependent insulinotropic polypeptide function. Diabetes 2010, 59:1228-1238.

81. Fonseca VA, Zinman B, Nauck MA, Goldfine AB, Plutzky J: Confronting the type 2 diabetes epidemic: the emerging role of incretin-based therapies. Am J Med 2010, 123:S2-S10.

82. Shaffer C: Incretin mimetics vie for slice of type 2 diabetes market. Nat Biotechnol 2007, 25:263.

83. Baggiio LL, Drucker DJ: Biology of incretins: GLP-1 and GIP. Gastroenterology 2007, 132:2131-2157.

84. Brinster RL, Chen HY, Trumbauer M, Senear AW, Warren R, Palmiter RD: Somatic expression of herpes thymidine kinase in mice following injection of a fusion gene into eggs. Cell 1981, 27:223-231.

85. Costantini F, Lacy E: Introduction of a rabbit beta-globin gene into the mouse germ line. Nature 1981, 294:92-94.

86. Gordon JW, Scangos GA, Plotkin DJ, Barbosa JA, Ruddle FH: Genetic transformation of mouse embryos by microinjection of purified DNA. Proc Natl Acad Sci U S A 1980, 77:7380-7384.

87. Wagner EF, Stewart TA, Mintz B: The human beta-globin gene and a functional viral thymidine kinase gene in developing mice. Proc Natl Acad Sci U S A 1981, 78:5016-5020.

88. Wagner TE, Hoppe PC, Jollick JD, Scholl DR, Hodinka RL, Gault JB: Microinjection of a rabbit beta-globin gene into zygotes and its subsequent expression in adult mice and their offspring. Proc Natl Acad Sci U S A 1981, 78:6376-6380.

89. Hyun S, Lee G, Kim D, Kim H, Lee S, Nam D, Jeong Y, Kim S, Yeom S, Kang $S$, et al: Production of nuclear transfer-derived piglets using porcine fetal fibroblasts transfected with the enhanced green fluorescent protein. Biol Reprod 2003, 69:1060-1068.

90. Lee GS, Kim HS, Hyun SH, Lee SH, Jeon HY, Nam DH, Jeong YW, Kim S, Kim $J H, H a n J Y$, et al: Production of transgenic cloned piglets from genetically transformed fetal fibroblasts selected by green fluorescent protein. Theriogenology 2005, 63:973-991.

91. Watanabe S, Iwamoto M, Suzuki S, Fuchimoto D, Honma D, Nagai T, Hashimoto M, Yazaki S, Sato M, Onishi A: A novel method for the production of transgenic cloned pigs: electroporation-mediated gene transfer to non-cultured cells and subsequent selection with puromycin. Biol Reprod 2005, 72:309-315.

92. Brinster RL, Chen HY, Trumbauer ME, Yagle MK, Palmiter RD: Factors affecting the efficiency of introducing foreign DNA into mice by microinjecting eggs. Proc Natl Acad Sci USA 1985, 82:4438-4442.

93. Garrick D, Fiering S, Martin DI, Whitelaw E: Repeat-induced gene silencing in mammals. Nat Genet 1998, 18:56-59.

94. Leahy P, Carmichael GG, Rossomando EF: Transcription from plasmid expression vectors is increased up to 14 -fold when plasmids are transfected as concatemers. Nucleic Acids Res 1997, 25:449-450.

95. Capecchi MR: The new mouse genetics: altering the genome by gene targeting. Trends Genet 1989, 5:70-76.

96. Capecchi MR: Altering the genome by homologous recombination. Science 1989, 244:1288-1292.

97. Koller $\mathrm{BH}$, Smithies $\mathrm{O}$ : Altering genes in animals by gene targeting Annu Rev Immunol 1992, 10:705-730.

98. Capecchi MR: How close are we to implementing gene targeting in animals other than the mouse? Proc Natl Acad Sci U S A 2000, 97:956-957.

99. Nagy A: Cre recombinase: the universal reagent for genome tailoring. Genesis 2000, 26:99-109.

100. Watanabe M, Umeyama K, Matsunari H, Takayanagi S, Haruyama E, Nakano K, Fujiwara T, Ikezawa Y, Nakauchi H, Nagashima $H$ : Knockout of exogenous EGFP gene in porcine somatic cells using zinc-finger nucleases. Biochem Biophys Res Commun 2010, 402:14-18.

101. Maeder ML, Thibodeau-Beganny S, Sander JD, Voytas DF, Joung JK: Oligomerized pool engineering (OPEN): an 'open-source' protocol for making customized zinc-finger arrays. Nat Protoc 2009, 4:1471-1501.

102. Remy S, Tesson L, Menoret S, Usal C, Scharenberg AM, Anegon I: Zinc-finger nucleases: a powerful tool for genetic engineering of animals. Transgenic Res 2010, 19:363-371.

103. Wright DA, Thibodeau-Beganny S, Sander JD, Winfrey RJ, Hirsh AS, Eichtinger M, Fu F, Porteus MH, Dobbs D, Voytas DF, et al: Standardized 
reagents and protocols for engineering zinc finger nucleases by modular assembly. Nat Protoc 2006, 1:1637-1652.

104. Urnov FD, Miller JC, Lee YL, Beausejour CM, Rock JM, Augustus S, Jamieson AC, Porteus MH, Gregory PD, Holmes MC: Highly efficient endogenous human gene correction using designed zinc-finger nucleases. Nature 2005, 435:646-651.

105. Carroll D, Beumer KJ, Morton JJ, Bozas A, Trautman JK: Gene targeting in Drosophila and Caenorhabditis elegans with zinc-finger nucleases. Methods Mol Biol 2008, 435:63-77.

106. Jakobsen JE, Li J, Kragh PM, Moldt B, Lin L, Liu Y, Schmidt M, Winther KD, Schyth BD, Holm IE, et al: Pig transgenesis by Sleeping Beauty DNA transposition. Transgenic Res 2011, 20:533-535.

107. Clark K, Carlson D, Fahrenkrug S: Pigs taking wing with transposons and recombinases. Genome Biol 2007, 8:S13.

108. Davidson AE, Balciunas D, Mohn D, Shaffer J, Hermanson S, Sivasubbu S, Cliff MP, Hackett PB, Ekker SC: Efficient gene delivery and gene expression in zebrafish using the Sleeping Beauty transposon. Dev Biol 2003, 263:191-202.

109. Ding S, Wu X, Li G, Han M, Zhuang Y, Xu T: Efficient transposition of the piggyBac (PB) transposon in mammalian cells and mice. Cell 2005, 122:473-483.

110. Dupuy AJ, Clark K, Carlson CM, Fritz S, Davidson AE, Markley KM, Finley K Fletcher CF, Ekker SC, Hackett PB: Mammalian germ-line transgenesis by transposition. Proc Natl Acad Sci USA 2002, 99:4495-4499.

111. Hamlet MR, Yergeau DA, Kuliyev E, Takeda M, Taira M, Kawakami K, Mead PE: Tol2 transposon-mediated transgenesis in Xenopus tropicalis. Genesis 2006, 44:438-445.

112. Kawakami K, Shima A, Kawakami N: Identification of a functional transposase of the Tol2 element, an Ac-like element from the Japanese medaka fish, and its transposition in the zebrafish germ lineage. Proc Natl Acad Sci USA 2000, 97:11403-11408.

113. Clark KJ, Carlson DF, Foster LK, Kong BW, Foster DN: Enzymatic engineering of the porcine genome with transposons and recombinases. BMC Biotechnol 2007, 7:42.

114. Carlson D, Garbe J, Tan W, Martin M, Dobrinsky J, Hackett P, Clark K, Fahrenkrug S: Strategies for selection marker-free swine transgenesis using the Sleeping Beauty transposon system. Transgenic Res 2011, 20:1-13.

115. Carlson DF, Geurts AM, Garbe JR, Park CW, Rangel-Filho A, O'Grady SM, Jacob HJ, Steer CJ, Largaespada DA, Fahrenkrug SC: Efficient mammalian germline transgenesis by cis-enhanced Sleeping Beauty transposition. Transgenic Res 2011, 20:29-45.

doi:10.1186/1755-8794-5-55

Cite this article as: Walters et al: Completion of the swine genome will simplify the production of swine as a large animal biomedical model. BMC Medical Genomics 2012 5:55.

\section{Submit your next manuscript to BioMed Central and take full advantage of:}

- Convenient online submission

- Thorough peer review

- No space constraints or color figure charges

- Immediate publication on acceptance

- Inclusion in PubMed, CAS, Scopus and Google Scholar

- Research which is freely available for redistribution 